\title{
QUALITY OF SOFT CHEESE MADE WITH GOAT'S MILK AS AFFECTED WITH THE ADDITION OF CERTAIN ESSENCES Hamad, M. N.F. ${ }^{1}$ and M.M. Ismail ${ }^{2}$ \\ 1 Food Science and Dairy Dept., Fac. Agric. "Qena", South Vally Univ. \\ 2 Dairy Technology Dept., Animal Production Res. Inst., Agric. Res. Center.
}

\begin{abstract}
In order to overcome the undesirable to many Egyptian consumers aroma of goats milk cheese, flavouring essences, namely (cream, butter, Cheddar cheese, Edam cheese, Gouda cheese and Emmental cheese) were added to cheese milk. Results indicated that there are no pronounced differences between control and other treatments for yield, acidity, $\mathrm{pH}$, fat, salt TN and TVFA contents. Cheese made using cream and butter flavouring essences had slightly higher WSN and NPN values, as compared with different samples. Sensory evaluation data showed that adding the above mentioned essences didn't affect the color \& appearance and body \& texture of the cheese while fresh or throughout the ripening period (90 days), whereas adding cream and butter essences improved the flavour of goat's milk cheese.

Keywords: Goat's milk- (cream, butter, Cheddar cheese, Edam cheese, Gouda cheese and Emmental cheese) flavours.
\end{abstract}

\section{INTRODUCTION}

Although the production and consumption of cow milk is the largest throughout the world, one may observe a growing demand for milk of other farm animals, such as goats, which is recognized in developed countries as a "niche" product (Haenlein \& Wendorff 2006 and Krzyżewski et al. 2009). In the past, the goat was known as the "poor man's cow", because people who were too poor to keep cows could support less-fussy goats. Globally goat production yields $60 \%$ of its value as milk, $35 \%$ as meat and $5 \%$ as skin (Davendra \& Mcleroy 1988 and Malau-Aduli et al., 2001). Webster (1989) reported that countries like Iraq and Libya obtain half of their total milk requirements from goats.

However, goat cheese now is a fashionable commodity in many countries, in Egypt great numbers of citizens do not prefer it because of its aroma. The specific aroma of goat cheese has been well identified by different authors (Ha \& Lindsay 1991; Queré et al., 1996; Sabio \& VidalAragón 1996; Sablé et al., 1997; Le Queré et al., 1998; Engel et al., 2002 and Carunchia-Whetstine et al., 2003). The fact that goat's milk contains about twice as much of capric, caprylic and caproic acids as does cow's milk has been claimed to be a reason for the characteristic odour and flavour associated with goat's milk (Lampert, 1975). Johnson \& Peterson (1974) indicated that the goat flavour is a genetic characteristic, but it can be affected by feed, environmental conditions, and the presence of the belly while milking. 4-methyloctanoic and 4-ethyloctanoic acids have been found to be the main volatile compounds responsible for the goat flavour and they are perceived at very low concentration (Brennand et al., 1989 and Salles et al., 2002). Therefore, the objective of this work was to study the quality of white 
cheese made from goat's milk as affected by adding some flavouring essences.

\section{MATERIALS AND METHODS}

Fresh goat's milk $(13.11 \%$ TS, $6.61 \mathrm{pH}, 0.17 \%$ titratable acidity, $4.1 \%$ fat and $3.42 \%$ total protein) was obtained from El-Serw Animal Production Research Station, Animal Production Research Institute, Agriculture Research Center. Egypt. Various flavouring essences were purchased from Flavours and Fragrances Factory, 6 October City, Egypt. Liquid calf rennet (single strength) was obtained from local market (Damietta city), and was added to milk in sufficient concentration required to coagulate milk within 40 min. Dry coarse commercial food grad salt was obtained from El-Nasr Salines Company, Egypt. Analytical grade calcium chloride obtained from ElGomhouria Company, Egypt.

White cheese was made as described by Abd El-kader (2003). Milk was divided into seven equal portions. The first was made without adding flavours and was considered as control (A). The other portions were mixed with the essences of Cream (B), Butter (C), Chedder cheese (D), Edam cheese $(E)$, Gouda cheese $(F)$ and Emmental cheese $(G)$.

Goat's milk of different above treatments was heated to $40^{\circ} \mathrm{C}$ then the flavouring essences $\mathrm{B}, \mathrm{C}, \mathrm{D}, \mathrm{E}, \mathrm{F}$ and $\mathrm{G}$ were added to milk at $0.04 \%$ (is usually ratio used in cheese factories). The admixture of milk and tastes was blinded at $2000 \mathrm{rpm} / 5 \mathrm{~min}$. Salt was added to all treatments $(A-G)$ at $12 \%$ and finally milk was renneted. After complete coagulation, the resultant curds were ladled in wooden frames, lined with muslin cloth. After 24 hours, the resultant cheese of all treatments were weighed and pickled into their own whey, and $0.04 \%$ flavouring essences were added also to the whey of the treatments. The cheese samples were stored in plastic jars at $25^{\circ} \mathrm{C}$ for 3 months. Samples of cheese were analyzed when fresh and after 15, 30, 60 and 90 days of ripening period. Three replicates of each treatment were conducted.

Each milk sample was analysed for the contents of titratable acidity (TA), total solids (TS), fat and total protein according to Ling (1963). The $\mathrm{pH}$ values were estimated using a $\mathrm{pH}$ meter type CG 710. Actual cheese yield was determined by dividing the weight of cheese by the weight of milk used to make cheese, multiplied by 100 . Adjusted cheese yield was calculated using the formula presented by Metzger et al. (2000):

Adjusted yield $=($ actual yield $\times(100-$ actual moisture + actual salt $)) /$ $(100-(55+1.5))$.

Each batch of white cheese was analyzed for dry matter, $\mathrm{pH}$, titrable acidity, fat, total nitrogen (TN), water soluble nitrogen (WSN) and non-proteinnitrogen (NPN), salt and total volatile fatty acids (TVFA) contents. Dry matter content was determined by drying at $102 \pm 2^{\circ} \mathrm{C}$ to a constant weight according to ISO 5534:2004. $\mathrm{pH}$ was determined by direct readings at $20 \pm 2^{\circ} \mathrm{C}$. Titratable acidity was expressed as \% lactic acid, and was determined by the titration of water solution of $10 \mathrm{~g}$ cheese with $0.1 \mathrm{~N} \mathrm{NaOH}$ using phenolphthalein as an indicator; fat content was determined by the Gerber 
butyrometric method, and total nitrogen, water soluble nitrogen (WSN) and non-protein-nitrogen (NPN) by the Kjeldahl method according to the AOAC (1995). Salt content was determined according the method described by Reddy \& Marth (1993). Salt-in-moisture content was calculated as the percentage of salt in the cheese, based on combined moisture plus salt content. Total volatile fatty acids (TVFA) were determined as described by Kosikowski (1978) and expressed as $\mathrm{ml}$ of $0.1 \mathrm{~N} \mathrm{NaOH} / 100 \mathrm{~g}^{-1}$ cheese. Chemical analyses were conducted in triplicate.

Professional panelists and staff members of the Faculty of Agriculture (Qina), South Valley University participated in sensory evaluation of cheese. Descriptive sensory analysis was carried out using a vocabulary of 50 taste \& flavour, 35 body and texture and 15 colour terms, which give a total score of 100 points.

\section{RESULTS AND DISCUSSION}

Results of cheese yield are listed in Table 1. Adding various flavouring essences to goat's milk had no clear effect on actual and adjusted yields of fresh white cheese. Actual yield of samples A, B, C and D were 25.51, 25.26, 25.17 and $25.30 \%$, respectively. Yield obtained by actual yield were higher than those by adjusted yield. Ratios of actual and adjusted yields for treatments $E$ and $F$ were 25.66, 17.87, 25.48 and $17.51 \%$, respectively.

Data in Table 1 describe the effect of adding different flavouring essences to goat's milk on the chemical composition of white cheese. The titratable acidity, $\mathrm{pH}, \mathrm{TS}$, fat, F/DM, salt and salt in moisture contents were nearly the same as control, and other treatments while fresh or during ripening period. Fat of treatments A, B, C, D, E, F and G were 20.5, 20.7, $20.6,20.6,20.7,20.3$ and $20.4 \%$, respectively, after 90 days of storage period.

On the other side, with the progressive of maturation period, the titratable acidity of cheese for all samples increased while $\mathrm{pH}$ values decreased. This might be due to the continuous fermentation of lactose to lactic acid, as well as the gradual increase of degradation products in the resultant cheese. These results are in agreement with those reported by Ayyad (2003). Also, TS, fat F/DM, salt and salt in moisture values had the same trend of acidity. F/DM ratios of sample $E$ at zero time and after 15, 30, 60 and 90 days of ripening period were 38.54, 41.79, 43.89, 44.23 and $45.60 \%$, respectively. Ismail and Osman (2004) illustrated that Fat/ DM contents of Domiati cheese made from goat's milk treatments significantly $(p<$ 0.001 ) increased as ripening period progresses reaching maximum values at the end of ripening period. This was probably attributed to the decrease in solids-not fat content as a result of protein degradation and its partial loss in whey during ripening as advocated by Fayed (1982). 
Table 1: Effect of adding some flavouring essences to goat's milk on yield and chemical composition of white cheese.

\begin{tabular}{|c|c|c|c|c|c|c|c|c|c|c|}
\hline & $\begin{array}{l}\text { Storage } \\
\text { period } \\
\text { (days) }\end{array}$ & $\begin{array}{c}\text { Actua } \\
\text { Yield } \\
\%\end{array}$ & $\begin{array}{l}\text { Adjusted } \\
\text { Yield }^{*} \%\end{array}$ & $\begin{array}{c}\text { Acidity } \\
\%\end{array}$ & $\begin{array}{c}\mathrm{pH} \\
\text { values }\end{array}$ & $\begin{array}{l}\text { TS } \\
\%\end{array}$ & $\begin{array}{c}\text { Fat } \\
\%\end{array}$ & $\underset{\%}{\text { Fat/DM }}$ & $\underset{\%}{\text { Salt }}$ & \begin{tabular}{|c|} 
Salt in \\
Moisture \\
$\%$
\end{tabular} \\
\hline \multirow{5}{*}{ A } & 0 & 25.51 & 17.47 & 0.40 & 6.47 & 36.34 & $\mid 14.1$ & 38.80 & 6.55 & 9.33 \\
\hline & 15 & & & 1.20 & 5.78 & 39.12 & 16.3 & 39.37 & 6.90 & 10.18 \\
\hline & 30 & - & - & 2.26 & 3.90 & 41.24 & 18.7 & 45.34 & 7.47 & 11.28 \\
\hline & 60 & - & - & 2.61 & 3.83 & 43.11 & $\mid 19.6$ & 45.46 & 7.57 & 11.74 \\
\hline & 90 & - & - & 2.87 & 3.75 & 44.89 & 20.5 & 45.67 & 7.87 & 12.50 \\
\hline \multirow{5}{*}{ B } & 0 & 25.26 & 17.48 & 0.39 & 6.49 & 36.70 & 14.0 & 38.15 & 6.60 & 9.44 \\
\hline & 15 & & & 1.17 & 5.80 & 39.94 & 16.3 & 40.81 & 6.93 & 10.34 \\
\hline & 30 & - & & 2.24 & 3.94 & 42.04 & 18.5 & 44.01 & 7.44 & 11.38 \\
\hline & 60 & 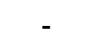 & - & 2.58 & 3.85 & 43.83 & 19.7 & 44.95 & 7.53 & 11.82 \\
\hline & 90 & - & - & 2.84 & 3.79 & 44.77 & 20.7 & 45.57 & 7.88 & 12.49 \\
\hline \multirow{5}{*}{ C } & 0 & 25.17 & 17.37 & 0.38 & 6.49 & 36.58 & 313.9 & 38.01 & 6.55 & 9.36 \\
\hline & 15 & 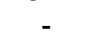 & & 1.16 & 5.81 & 40.24 & 16.1 & 40.01 & 6.90 & 10.35 \\
\hline & 30 & - & - & 2.22 & 3.94 & 41.76 & 18.7 & 44.78 & 7.43 & 11.31 \\
\hline & 60 & & & 2.62 & 3.84 & 43.20 & 19.4 & 44.91 & 7.58 & 11.77 \\
\hline & 90 & & & 2.88 & 3.76 & 45.10 & 20.6 & 45.68 & 7.90 & 12.58 \\
\hline \multirow{5}{*}{ D } & 0 & 25.30 & 17.81 & 0.39 & 6.48 & 37.12 & 14.1 & 37.98 & \begin{tabular}{|l|}
6.49 \\
\end{tabular} & 9.35 \\
\hline & 15 & & & 1.17 & 5.80 & 40.30 & 16.2 & 40.20 & 6.88 & 10.33 \\
\hline & 30 & - & & 2.23 & 3.93 & 42.62 & 18.9 & 44.34 & 7.49 & 11.55 \\
\hline & 60 & - & - & 2.63 & 3.81 & 44.01 & & & 7.59 & 11.94 \\
\hline & 90 & - & - & 2.86 & 3.77 & 44.94 & 20.6 & 45.83 & 7.90 & 12.55 \\
\hline \multirow{5}{*}{$E$} & 0 & 25.66 & 17.87 & 0.40 & 6.47 & 36.84 & $\mid 14.2$ & 38.54 & 6.54 & 9.38 \\
\hline & 15 & & 110. & 1.18 & 5.78 & 39.24 & 16.4 & 41.79 & 6.87 & 10.16 \\
\hline & 30 & - & - & 2.22 & 3.94 & 42.15 & 18.5 & 43.89 & 7.51 & 12.04 \\
\hline & 60 & - & & 2.62 & 3.82 & 43.86 & 19.4 & 44.23 & 7.59 & 11.91 \\
\hline & 90 & - & - & 2.89 & 3.73 & 44.5 & 2 & 45.60 & 7.92 & 12.49 \\
\hline \multirow{5}{*}{$\mathrm{F}$} & 0 & 25.48 & 17.51 & 0.39 & 6.48 & 36.42 & 13.9 & 38.16 & \begin{tabular}{|l|}
6.53 \\
\end{tabular} & 9.31 \\
\hline & 15 & & & 1.16 & 5.81 & 100 & & & 6.93 & 10.37 \\
\hline & 30 & - & - & 2.23 & 3.92 & 41.85 & 18.9 & 45.16 & 7.49 & 11.41 \\
\hline & 60 & - & - & 2.61 & 3.84 & 44.09 & & 44.45 & 7.60 & 11.97 \\
\hline & 90 & - & - & 2.86 & 3.76 & 45.21 & 20.7 & 45.78 & 7.87 & 12.56 \\
\hline \multirow{5}{*}{ G } & & 25.32 & 17.32 & 0.38 & 6.49 & 36.36 & $\mid 13.8$ & 37.95 & \begin{tabular}{|c|}
6.61 \\
\end{tabular} & 9.41 \\
\hline & 15 & & & 1.17 & 5.82 & 39.44 & 15.9 & 40.31 & 6.94 & 10.30 \\
\hline & 30 & & & 2.24 & 3.95 & 42.34 & 418.5 & 43.69 & 7.53 & 11.55 \\
\hline & 60 & & & 2.64 & 3.80 & 43. & & 44.47 & 7.60 & 11.88 \\
\hline & 90 & & & 2.88 & 3.75 & 44.80 & 20.4 & 45.53 & 7.86 & 12.46 \\
\hline
\end{tabular}

${ }^{*}$ moisture and salt adjusted cheese yield.

Table 2 represents the change in TN, TN/DM, WSN, WSN/TN, NPN, NPN/TN and TVFA contents of white cheese as a result of adding some essences to goat's milk. Both the control cheese and various samples approximately possessed the same levels of TN and TVFA contents. Total nitrogen values of $A, B, C$ and $D$ treatments were 2.91, 291, 2.90 and $2.92 \%$, respectively, after 60 days of ripening period. Slight increase in WSN and NPN values was noticed in treatments $B$ and $C$ (cream and butter tastes), comparing with other treatments. Values of WSN were $0.691,0.703,0.702$ and $0.690 \%$ for samples $A, B, C$ and $G$ at the end of ripening period, 
respectively. On the other hand, TN, TN/DM, WSN, WSN/TN, NPN, NPN/TN and TVFA contents in all cheese samples increased with the progress of ripening period. Similar results were found by Ismail et al. (2010). On the contrary, Prasad \& Alvarez (1999) and Talib et al (2009) reported that the decrease in the protein content during pickling as a result of protein degradation leading to the formation of water soluble compound, and some of which losses in the pickling solution, leading to increase of the nitrogen content in whey.

Table 2: Effect of adding some flavouring essences to goat's milk on TN and some ripening indices of white cheese.

\begin{tabular}{|c|c|c|c|c|c|c|c|c|}
\hline Treatments & $\begin{array}{l}\text { Storage } \\
\text { period } \\
\text { (days) }\end{array}$ & TN \% & $\begin{array}{c}\text { TN/DM } \\
\%\end{array}$ & $\begin{array}{c}\text { WSN } \\
\%\end{array}$ & $\begin{array}{c}\text { WSN/TN } \\
\%\end{array}$ & NPN \% & $\begin{array}{c}\text { NPN/TN } \\
\%\end{array}$ & TVFA* \\
\hline \multirow{5}{*}{ A } & 0 & 2.41 & 6.63 & 0.277 & 11.49 & 0.114 & 4.73 & 7.0 \\
\hline & 15 & 2.50 & 6.39 & 0.340 & 13.60 & 0.147 & 5.88 & 11.8 \\
\hline & 30 & 2.66 & 6.45 & 0.432 & 16.24 & 0.181 & 6.80 & 14.8 \\
\hline & 60 & 2.91 & 6.75 & 0.541 & 18.59 & 0.199 & 6.84 & 19.4 \\
\hline & 90 & 2.98 & 6.64 & 0.691 & 23.19 & 0.223 & 7.48 & 25.8 \\
\hline \multirow{5}{*}{ B } & 0 & 2.39 & 6.51 & 0.285 & 11.92 & 0.120 & 5.02 & 7.0 \\
\hline & 15 & 2.48 & 6.21 & 0.349 & 14.07 & 0.155 & 6.25 & 11.9 \\
\hline & 30 & 2.67 & 6.35 & 0.441 & 16.52 & 0.185 & 6.93 & 15.1 \\
\hline & 60 & 2.91 & 6.64 & 0.550 & 18.90 & 0.204 & 7.01 & 19.3 \\
\hline & 90 & 2.97 & 6.63 & 0.703 & 23.67 & 0.228 & 7.68 & 26.0 \\
\hline \multirow{5}{*}{ C } & 0 & 2.43 & 2.64 & 0.287 & 11.81 & 0.119 & 4.50 & 7.2 \\
\hline & 15 & 2.51 & 6.24 & 0.348 & 13.86 & 0.157 & 6.25 & 12.0 \\
\hline & 30 & 2.65 & 6.34 & 0.444 & 16.75 & 0.186 & 7.02 & 15.0 \\
\hline & 60 & 2.90 & 6.71 & 0.549 & 18.93 & 0.206 & 7.10 & 19.4 \\
\hline & 90 & 2.99 & 6.63 & 0.702 & 23.48 & 0.230 & 7.69 & 25.9 \\
\hline \multirow{5}{*}{ D } & 0 & 2.41 & 6.49 & 0.275 & 11.41 & 0.111 & 4.60 & 7.3 \\
\hline & 15 & 2.53 & 6.28 & 0.342 & 13.52 & 0.148 & 5.85 & 11.8 \\
\hline & 30 & 2.68 & 6.29 & 0.435 & 16.23 & 0.180 & 6.72 & 15.0 \\
\hline & 60 & 2.92 & 6.63 & 0.542 & 18.56 & 0.197 & 6.75 & 19.6 \\
\hline & 90 & 2.99 & 6.65 & 0.690 & 23.07 & 0.224 & 7.49 & 26.1 \\
\hline \multirow{5}{*}{$E$} & 0 & 2.40 & 6.51 & 0.279 & 11.62 & 0.115 & 4.79 & 7.0 \\
\hline & 15 & 2.50 & 6.37 & 0.344 & 13.76 & 0.153 & 6.12 & 12.1 \\
\hline & 30 & 2.64 & 6.26 & 0.438 & 16.59 & 0.183 & 6.93 & 14.7 \\
\hline & 60 & 2.88 & 6.57 & 0.540 & 18.75 & 0.198 & 6.87 & 19.3 \\
\hline & 90 & 2.97 & 6.67 & 0.694 & 23.37 & 0.225 & 7.57 & 25.8 \\
\hline \multirow{5}{*}{$\mathrm{F}$} & 0 & 2.39 & 6.56 & 0.278 & 11.63 & 0.114 & 4.77 & 6.9 \\
\hline & 15 & 2.51 & 6.26 & 0.347 & 13.82 & 0.150 & 5.98 & 12.0 \\
\hline & 30 & 2.65 & 6.33 & 0.436 & 16.45 & 0.181 & 6.83 & 15.2 \\
\hline & 60 & 2.89 & 6.55 & 0.545 & 18.86 & 0.198 & 6.85 & 19.5 \\
\hline & 90 & 2.98 & 6.59 & 0.693 & 23.25 & 0.223 & 7.48 & 26.2 \\
\hline \multirow{5}{*}{ G } & 0 & 2.42 & 6.65 & 0.276 & 11.40 & 0.112 & 4.63 & 7.1 \\
\hline & 15 & 2.53 & 6.41 & 0.343 & 13.55 & 0.151 & 5.97 & 11.7 \\
\hline & 30 & 2.68 & 6.33 & 0.439 & 16.38 & 0.184 & 6.86 & 15.3 \\
\hline & 60 & 2.90 & 6.65 & 0.540 & 18.62 & 0.200 & 6.90 & 19.4 \\
\hline & 90 & 2.99 & 6.67 & 0.690 & 23.08 & 0.224 & 7.49 & 26.0 \\
\hline
\end{tabular}


Flavor is the sensation produced by a material taken in the mouth, perceived principally by the senses of taste and smell, and also by the general pain, tactile, and temperature receptors in the mouth. Flavor also denotes the sum of the characteristics of the material which produces that sensation.

The organoleptic properties of fresh white cheese treatments and during the ripening period are presented in Table 3. As shown, there are no clear differences between control and other cheese samples in color and appearance values. The scores of color and appearance at the end of ripening stage for treatments $A, B, C$ and $D$ were 14, 14, 14 and 14 , respectively.

Table 3: Effect adding some flavouring essences to goat's milk on organoleptic properties of white cheese.

\begin{tabular}{|c|c|c|c|c|c|}
\hline Treatments & $\begin{array}{l}\text { Storage } \\
\text { period } \\
\text { (days) }\end{array}$ & $\begin{array}{c}\text { Color \& } \\
\text { Appearance } \\
(15)\end{array}$ & $\begin{array}{c}\text { Body\& } \\
\text { Texture } \\
\text { (35) }\end{array}$ & $\begin{array}{c}\text { Taste \& } \\
\text { Flavor } \\
(50)\end{array}$ & $\begin{array}{l}\text { Total } \\
(100)\end{array}$ \\
\hline \multirow{5}{*}{ A } & 0 & 13 & 29 & 28 & 70 \\
\hline & 15 & 13 & 32 & 31 & 76 \\
\hline & 30 & 13 & 33 & 33 & 79 \\
\hline & 60 & 13 & 33 & 35 & 81 \\
\hline & 90 & 14 & 33 & 37 & 84 \\
\hline \multirow{5}{*}{ B } & 0 & 13 & 30 & 32 & 75 \\
\hline & 15 & 13 & 32 & 35 & 80 \\
\hline & 30 & 13 & 33 & 38 & 84 \\
\hline & 60 & 14 & 33 & 42 & 89 \\
\hline & 90 & 14 & 33 & 46 & 93 \\
\hline \multirow{5}{*}{ C } & 0 & 13 & 30 & 31 & 74 \\
\hline & 15 & 13 & 31 & 36 & 80 \\
\hline & 30 & 13 & 33 & 39 & 85 \\
\hline & 60 & 13 & 33 & 42 & 88 \\
\hline & 90 & 14 & 34 & 47 & 95 \\
\hline \multirow{5}{*}{ D } & 0 & 13 & 29 & 30 & 72 \\
\hline & 15 & 13 & 32 & 32 & 77 \\
\hline & 30 & 13 & 33 & 35 & 81 \\
\hline & 60 & 13 & 33 & 37 & 83 \\
\hline & 90 & 14 & 33 & 40 & 87 \\
\hline \multirow{5}{*}{$E$} & 0 & 12 & 30 & 31 & 73 \\
\hline & 15 & 13 & 32 & 33 & 78 \\
\hline & 30 & 13 & 32 & 36 & 81 \\
\hline & 60 & 13 & 33 & 39 & 85 \\
\hline & 90 & 14 & 33 & 41 & 88 \\
\hline \multirow{5}{*}{$\mathrm{F}$} & 0 & 13 & 28 & 30 & 71 \\
\hline & 15 & 13 & 30 & 33 & 76 \\
\hline & 30 & 13 & 32 & 36 & 81 \\
\hline & 60 & 13 & 33 & 39 & 85 \\
\hline & 90 & 13 & 34 & 40 & 87 \\
\hline \multirow{5}{*}{$\mathrm{G}$} & 0 & 13 & 30 & 29 & 72 \\
\hline & 15 & 13 & 31 & 32 & 76 \\
\hline & 30 & 13 & 33 & 35 & 81 \\
\hline & 60 & 13 & 33 & 37 & 83 \\
\hline & 90 & 13 & 33 & 40 & 86 \\
\hline
\end{tabular}


Similar to color and appearance, the cheese made from goat's milk blended with various flavouring essences showed body and texture scores very closed to control cheese. Body and texture results of samples E, F and G were 32,33 and 33 , respectively, after 60 days of ripening period. It is noticed from Table 3 that most differences between various treatments were in taste \& flavour scoring. The sample $\mathrm{C}$ (butter taste) had the highest flavour scores either fresh or during ripening. Also, the sample B (cream taste) showed higher score, as compared with control or D, E, F and $G$ treatments. The flavour scores of treatments A, B and C were 37,46 and 47 , respectively, after 90 days of maturation period. On the other hand, adding Cheddar, Edam, Gouda and Emmental cheese essences to goat's milk slightly improved the cheese flavour. This is might be explained by the different aroma of these flavouring essences than the white soft cheese flavour.

In all cheese treatments, the sensory evaluation scores gradually increased during ripening period. The total scores of organoleptic properties of samples C were 74,80 and 85 , respectively, at the beginning of ripening period and after 15 and 30 days. These results agreed with those of AlJasser \& Al-Dogan (2009).

\section{Conclusion}

In conclusion, adding of cream or butter essences $(0.04 \%)$ to goat's milk could be recommended for improvement of white goat's cheese quality.

\section{REFERENCES}

Abd El-kader, Y. I. (2003). Changes in the nitrogen fractions of Domiati cheese made with microbial and recombinant rennets during ripening. Egyptian. J. Dairy Sci., 31: 111.

Al-Jasser, M. S. and Al-Dogan, A. A. (2009). Properties of white soft cheese produced using rennet substitute extracted from Solanum dubium seeds. Egyptian J. Dairy Sci., 37:237-243.

Association of Official Analytical Chemists (1995). Official Methods of Analysis, Vol. II, 16th ed., AOAC, Arlington, VA (1995) Secs. 33.2.11.

Ayyad, K. M. K. (2003). Studies on some dairy products. Ph.D. Thesis, Fac. of Agric., Mansoura Univ., Egypt.

Brennand, C. P., Ha, J. K. and Lindsay, R. C. (1989). Aroma properties and threshold of some branched-chain and other minor volatile fatty acids occurring in milkfat and meat lipids, J. Sens. Stud. 4: 105-120.

Carunchia-Whetstine, M. E., Karagul-Yuceer, Y., Avsar, Y. K. and Drake, M. A. (2003). Identification and quantification of character aroma components in fresh chevre-style goat cheese, Food Chem. Toxicol. 68: 2441-2447.

Davendra, C. and McLeroy, G. B. (1988). Sheep and Goat Production in the Tropics, pp: 271. ELBS Longman Ltd., Singapore.

Engel, E., Lombardot, J. B., Garem, A., Leconte, N., Septier, C., Le Queré, J. L. and Salles, C. (2002). Fractionation of the water-soluble extract of a cheese made from goats' milk by filtration methods: behavior of fat and volatile compounds, Int. Dairy J. 12: 609-619. 
Fayed, E. O.(1982). Studies on the use of some natural flavour agents on the ripening of pickled Domiati cheese. Ph.D. Thesis Ain Shams Univ.

Ha, J. K. and Lindsay, R. C. (1991). Contribution of cow, sheep and goat milks to characterizing branched-chain fatty acid and phenolic flavours in varietal cheeses, J. Dairy Sci. 74: 3267-3274.

Haenlein, G. F. W. and Wendorff, W. L. (2006). Sheep Milk - Production and Utilization of Sheep Milk. In: Handbook of Milk of Non-Bovine Mammals. Blackwell Publishing Professional, Oxford, UK, and Ames, lowa, USA, 137-194.

Ismail, M. M., Ammar, E. M. A., El-Shazly, A. A. and Eid, M. Z. (2010). Impact of cold storage and blending different lactations of cow's milk on the quality of Domiati cheese. African J. Food Sci. 4(6) 503-513.

Ismail, M. M. and Osman, M. M. (2004). Effect of adding some herbs to goat feed on the chemical, microbiological and organoleptic properties of Domiati cheese. J. Agric. Sci. Mansoura Univ., 29(1): 253-263.

Kosikowski, F. V. (1978). Cheese and Fermented Milk Food. 3rd ed., Published by the author, Cornell Univ., Ithaca, New York, USA.

Krzyzewski, J., Strzalkowska, N., Jozwik, A., Bagnicka, E. and Horbanczuk, J.O. (2009). Nutritive value and functional properties of goat milk. Proceedings of the International Conference on Improvement of Quality of Animal Products Obtained in Sustainable Production Systems with Special Reference to Bioactive Components and their Benefit for Human Health. Jastrzębiec, 14-15 May, 41-48.

Le Queré, J. L., Pierre, A., Riaublanc, A. and Demaizières, D. (1998). Characterization of aroma compounds in the volatile fraction of soft goat cheese during ripening, Lait 78: 279-290.

Le Quéré, J. L., Septier, C., Demaizières, D. and Salles, C. (1996). Identification and sensory evaluation of the character-impact compounds of goat cheese flavour, Eighth Weurman Flavour Research Symposium, Reading, July 23-26, Royal Society of Chemistry, Cambridge, UK.

Ling, E. R. (1963). A text-book of Dairy Chemistry. Vol. 2, Practical, $3^{\text {rd }}$ Ed., Champan and Hall, London, England.

Malau-Aduli, B. S., Eduvie, I. O. Lakpini, C. A. M. and Malau-Aduli, A. E. O. (2001). Effect of supplementation on the milk yield of Red Sokoto does. Proc. of the $26^{\text {th }}$ Annual Conference of Nigerian Society of Animal Production, pp: 353-355. March, ABU, Zaria, Nigeria.

Metzger, L. E., Barbano, D. M., Rudan, M. A. and Kindstedt, P. S. (2000). Effect of milk preacidification on low fat Mozzarella cheese. I. Composition and yield. J. Dairy Sci., 83:648-658.

Prasad, N. and Alvarez, V. B. (1999). Effect of salt and chymosin on the physicochemical properties of feta cheese during ripening. Ibid, 82: 1061.

Reddy, K. A. and Marth, E. H. (1993). Composition of Cheddar cheese made with sodium chloride and potassium chloride either singly or as mixtures. J. Food Comp. Anal., 6: 354-363.

Sabio, E. and Vidal-Aragón, C. (1996). Análisis de la fracción volátil del queso de los Ibores, Alimentaria 278: 101-103. 
Sablé, S., Letellier, F. and Cottenceau, G. (1997). An analysis of the volatile flavour compounds in a soft raw goat milk cheese, Biotechnol. Lett. 19: 143-145.

Salles, C., Sommerer, N., Septier. C., Issanchou, S., Chabanet, C., Garem, A. and Le Quéré J. L. (2002). Goat cheese flavor: sensory evaluation of branched-chain fatty acids and small peptides, J. Food Sci. 67: 835841.

Talib, M. A., Abubakar, M. M., Jideani, I. A. and Hassan. A. (2009). Use of Jiben seeds extract to manufacture soft white cheese. American J. Applied Sci., 6 (4): 551-554.

Webster, C. C., (1989). Agricultural Production in the Tropics, pp: 357-370. Longman Inc. New York.

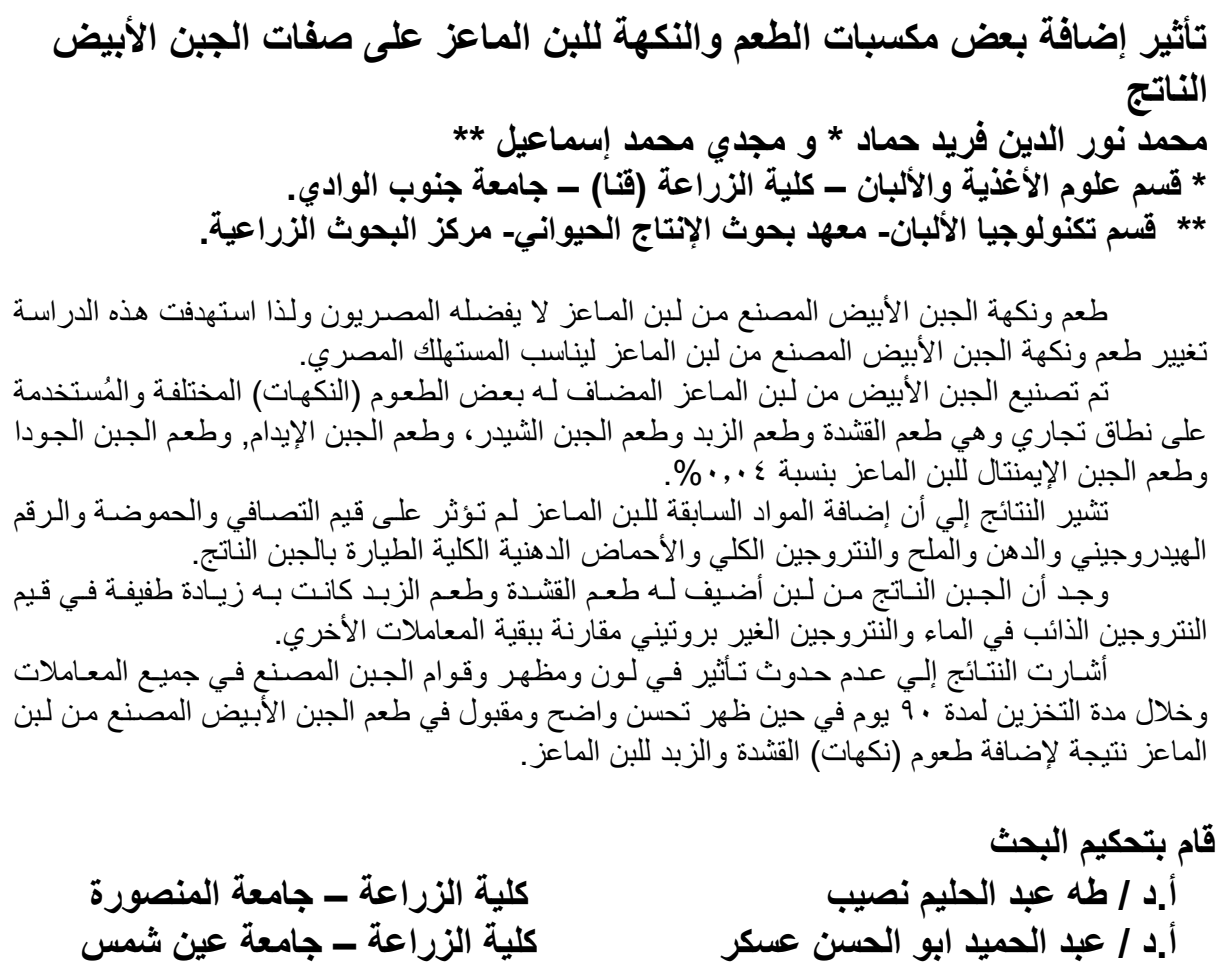

كلية الزراعة - جامعة المنصورة

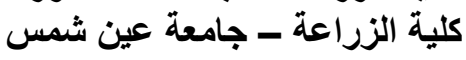

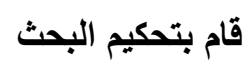

أ.د / أد / طبد الحميد ابليو الحسن عسكر 